\title{
KEKUASAAN DAN KEIMANAN \\ DALAM KELUARGA PERMANA \\ KARYA RAMADHAN K.H.
}

\author{
Langgeng Prima Anggradinata \\ Universitas Indonesia \\ Jl. Salemba Raya No. 6, Jakarta Pusat 10430 \\ E-Mail: anggradinata17@gmail.com \\ HP. +62-217867222
}

Abstrak: A religion-nuanced literary work has a meaning that is more than just the understanding of whether a religious teaching is right or wrong. It is really meaningful and presents various problems that can give a discourse to its readers. One of such literary works is a novel written by Ramadhan K.H., entitled Keluarga Permana. This novel attracts its audience when it is approached with Foucault's theory of power and James Fowler's faith development theory. These two theories allow readers to uncover many things contained in the novel. Using Foucault's theory of power, power relations can be seen. In addition, through this approach, it can also be seen the occurrence of a new character named society, which takes a role of supervising the power system and giving motivation to the other characters. Meanwhile, through James Fowler's faith development theory, the faith of Farida - one character in the novel - can be easily analyzed and shown the problems.

Kata kunci: power, faith, ethics, religiosity.

Abstrak: Karya sastra bercorak agama memiliki makna yang tidak hanya terbatas pada pemahaman benar dan yang salah seperti sebuah ajaran agama, namun lebih dari itu. Karya sastra bercorak agama menunjukkan kekayaan makna dan keberagaman persoalan yang lebih sering memberikan diskursus kepada pembacanya. Novel Keluarga Permana karya Ramadhan K.H. menjadi salah satu karya sastra bercorak agama yang memiliki itu. Novel ini menjadi menarik apabila didekati melalui teori kekuasaan Michel Foucault dan teori perkembangan keimanan James Fowler. Melalui dua pendekatan tersebut, dapat dilihat apa-apa yang terdapat dalam novel Keluarga Permana secara lebih mendalam. Melalui pendekatan kekuasaan Foucault, relasi-relasi kuasa akan nampak. Selain itu, pendekatan kekuasaan akan muncul tokoh baru yang bernama masyarakat yang menjadi 
pengawas sistem kuasa dan memberi motivasi tindakan terhadap tokohtokoh lainnya. Sementara itu, melalui teori perkembangan keimanan James Fowler, keimanan tokoh Farida akan dengan mudah diuraikan dan ditemukan problematikanya.

Kata kunci: kekuasaan, keimanan, etika, religiusitas.

\section{A. Pendahuluan}

Saridjo (2006: 1-3) melihat dalam kesusastraan Indonesia, perhatian terhadap karya sastra bercorak agama dimulai pada dekade 1960-an. Beberapa nama muncul di majalah Sastra yang diredakturi oleh H.B. Jassin, di antaranya Aoh K. Hadimadja, A.A. Navis, Kuntowidjoyo, dll. Sementara itu, Rosidi (1972: 172-173) melihat bahwa pada tahun tersebut bermunculan pula pengarangpengarang keagamaan. Para pengarang tersebut umumnya lahir dari Lesbumi, lembaga underbow NU. Ada juga Lembaga Kebudayaan Kristen (Lekrindo) dan para pengarang Katolik yang menulis di majalah Basis. Di antara pengarang yang mengetengahkan persoalan agama dan berkarya sebelum dan pada dekade 1960-an, Ramadhan K.H. adalah nama yang mahsyur. Ia menerbitkan novelnya yang bercorak keagamaan yang berjudul Keluarga Permana.

Novel Keluarga Permana bercerita tentang sebuah keluarga yang tinggal di Kota Bandung. Keluarga tersebut terdiri dari Permana (ayah), Saleha (ibu), dan Farida (anak). Karena Permana tidak memiliki pekerjaan lagi, ia pun menyewakan satu kamar di rumahnya kepada Sumarto. Konflik pun bermula ketika Sumarto menjalin hubungan dengan Farida. Singkat cerita, Farida pun dihamili oleh Sumarto. Mengetahui hal tersebut, Permana dan Saleha tidak tinggal diam. Karena dibayang-bayangi rasa malu, mereka pun mencoba menggugurkan kandungan Farida dengan cara meminumkan anak SMA itu dengan obat penggugur kandungan. Kandungan Farida pun gugur. Dalam pada it u, Farida merasa bahwa dirinya tidak berharga lagi jika ia tidak menikah dengan Sumarto. Namun, perkawinan itu terkendala masalah agama; Sumarno adalah Kristen, sementara Farida adalah Islam. Meskipun begitu, tekad Farida telah kuat, ia merasa tidak berarti tanpa Sumarto. Akhirnya, karena Sumarto tidak mau dan tidak mungkin masuk Islam, Farida pun terpaksa masuk Kristen. Hal tersebut tentu saja membuat sedih perasaan Permana dan Saleha. Mereka terpaksa rela. Pada gilirannya, mereka harus menyesal at as apa yang telah mereka perbuat terhadap Farida soal penguguran janin itu. Ternyata obat pengugur itu berefek sangat buruk dan menjadi penyebab kematian Farida. Hal 
yang jadi permasalahan adalah apakah Farida benar-benar Kristen atau masih tetap Islam hingga akhir hayatnya?

Sepintas persoalan yang terdapat dalam novel ini sangat sederhana, hanya bercerita mengenai keluarga dan masalah pindah agama. Mungkin dapat dengan mudah pembaca menangkap makna dari novel ini, bahkan menjawab pertanyaan pada alinea sebelumnya. Namun, apabila dilihat dari kacamata yang lain, persoalan dalam novel ini cukup kompleks, yakni (1) bagaimana sistem disiplin (meminjam term Foucault) bekerja dalam realit as cerita di novel ini yang kemudian memengaruhi relasi antar tokohnya dan (2) bagaimana suatu kelompok menjadi pengawas keimanan dan berhak menentukan keimanan seseorang. Pendekatan kekuasaan ini menjadi penting karena pendekatan ini agaknya jarang diterapkan dalam karya sastra, teruma dalam hal ini karya sastra bercorak keagamaan.

Dalam pada itu, pengkajian novel Keluarga Permana menjadi penting untuk karya sastra itu sendiri, maupun unt uk tradisi pengkajian karya sastra, khususnya karya sastra bercorak agama. Dalam tulisan ini, novel tersebut akan dikaji menggunakan pendekatan kekuasaan Foucault. Hal tersebut berarti, kajian tidak lagi berfokus pada isi yang kemudian berakhir pada simpulan nilainilai keagamaan, bahkan sampai pada justifikasi profan atau tidaknya suatu karya. Pendekatan ini lebih universal, melihat representasi budaya dalam suatu karya sastra (bercorak agama); bagaimana sistem disiplin (kuasa) bekerja pada tokoh-tokohnya, bahkan sistem disiplin ini bekerja hingga persoalan keimanan. Oleh sebab itu, tulisan ini beberapa persoalan akan digali dalam tulisan ini, di antaranya (1) tulisan ini akan menggali sistem disiplin yang bekerja dalam realitas cerita yang kemudian berpengaruh terhadap relasi antar tokoh. Selanjutnya, (2) bagaimana suatu kelompok menjadi pengawas keimanan dan berhak menentukan keimanan seseorang. Melalui pendekatan ini, tulisan ini akan mencoba memperoleh makna yang lebih dalam dari novel ini.

\section{B. KeKuasaAn dan Keimanan}

\section{Relasi Kuasa dan Sistem Disiplin dalam Keluarga Permana}

Kekuasaan menjadi unsur yang kuat dalam novel ini. Kekuasaan dalam pemikiran Foucault memiliki arti yang berbeda. Ia telah menemukan bentuk kekuasaan baru. Dalam pemikirannya, ia melihat bahwa kekuasaan telah berubah wujud; dari kekuasaan tradisional ke kekuasaan modern. Menurutnya, manusia telah memasuki era kekuasaan modern di mana suatu kekuasan tidak terinstitusi. Seperti apa yang kemukakan oleh Foucault bahwa kekuasaan 
"bukan himpunan lembaga dan perangkat yang menjamin kepatuhan warga negara dalam suatu negara tertentu". Kekuasaan di sini dapat diartikan sebagai "suatu sistem dominasi global yang dilakukan oleh suatu unsur atau kelompok atas yang lain, dan yang karena disalurkan secara berturut-turut, dampaknya melanda masyarakat seutuhnya" (2008: 120).

Dalam konsep Foucault, kekuasaan modern ini merupakan kekuasaan yang abstrak, global, transnasional sistemik yang (bisa jadi) diampu oleh "suatu unsur" atau "kelompok atas yang lain". Ia tidak dimiliki manusia, tetapi menjadi suatu sistem yang bekerja dalam alam bawah sadar manusia. Manusia atau masyarakat hanya menjadi pengawas atau penjamin kekuasaan itu tetap langgeng. Oleh sebab itu, dalam hal ini akan dilihat cara kekuasaan itu bekerja dalam alam bawah sadar setiap tokoh dalam novel ini.

Kekuasaan adalah nama yang diberikan kepada suatu situasi strategis yang rumit dalam masyarakat (2008: 121-122). Gambaran di atas memperlihatkan bahwa kekuasaan tidak lagi mengenai kekuasaan dan negara, melainkan mengenai kekuasaan dan subjek. Jika begitu, hal ini berarti kekuasaan memiliki hubungan yang banyak. Kekuasaan terbentuk dari pemisahan, ketidaksamaan, ketidakseimbangan (diskriminasi). Artinya, kekuasaan terjadi dalam situasi di mana ada suatu perbedaan. Misalnya dalam keluarga, antara suami dan istri, orang tua dan anak, atau antara jamaat dan Pastor. Dalam novel ini, akan terlihat bagaimana relasi kuasa itu terjalin di antara tokoh-tokohnya.

Menurut Foucault, kekuasaan berbentuk sistem disiplin. Sistem disiplin ini dibentuk oleh epistemé, ilmu pengetahuan, dan wacana. Bartky (1990: 27) memberikan contoh yang cukup nyata, yaitu sistem disiplin dalam bentuk gambaran tentang wanita modern. Menurut Bartky, perempuan modern ialah yang bertubuh langsing, berkulit halus, dan menggunakan mode fesyen masa kini. Oleh sebab itu, perempuan-perempuan berusaha memenuhi standar itu untuk disebut modern. Di sinilah sistem disiplin dan kekerasan simbolik bekerja bahwa perempuan harus datang ke gym untuk menjaga berat badan mereka; ia harus pergi ke mal untuk menjaga fesyen mereka; dan pergi ke klinik kecantikan untuk menjaga tubuh mereka.

Dalam penjelasan Bartky tersebut dapat dilihat bagaimana epistemé zaman modern, wacana perempuan modern, dan ilmu pengetahuan (sosial, kedokteran, ekonomi, dll) membent uk sistem disiplin berupa gambaran perempuan modern. Kemudian, sistem tersebut bekerja dalam benak perempuan. Dalam novel Keluarga Permana, salah satu unsur yang membentuk sistem disiplin itu ialah etika. 
Etika di sini termasuk pada pengertian-pengertian etika sebagai ilmu tentang norma dan etika sebagai norma itu sendiri. Bartens (2001:6) memberi tiga pengertian mengenai etika. Pengertian pertama berkaitan dengan etika sebagai "norma-norma atau nilai yang menjadi pegangan bagi seseorang atau masyarakat yang mengat ur tingkah lakunya". Dalam pengertian ini, etika memiliki berbagai macam jenis tergantung masyarakat penganutnya, misalnya etika orang Sunda, etika Protestan, dan etika Islam. Ketiga etika itu-lah yang bekerja dalam mengatur tindak-tanduk tokoh-tokoh dalam novel ini. Pengertian kedua, yakni etika dipahami sebagai kumpulan asas dan nilai moral; misalnya, kode etik rumah sakit, dll. Pengertian ketiga ialah etika sebagai ilmu tentang yang baik dan yang buruk. Pengertian pertama dan ketiga sangat relevan dengan apa yang disebut sistem disiplin tadi. Pengertian pertama dapat disebut sebagai epistemé dan wacana, sedangkan pengertian kedua dapat disebut dengan ilmu pengetahuan. Kembali lagi kepada Foucault, bahwa kekuasaan dibentuk dari epistemé, wacana, dan ilmu pengetahuan. Kiranya, itulah yang hadir dalam novel Keluarga Permana ini.

Dalam pada itu, dapat dilihat bagaimana sistem disiplin bekerja dalam setiap tindakan tokoh dalam novel ini. Sistem disiplin tersebut berupa bisa "gambaran tentang keluarga ideal", "superioritas laki-laki”, "etika atau norma yang ada dalam masyarakat". Gambaran-gambaran tersebutlah yang kemudian

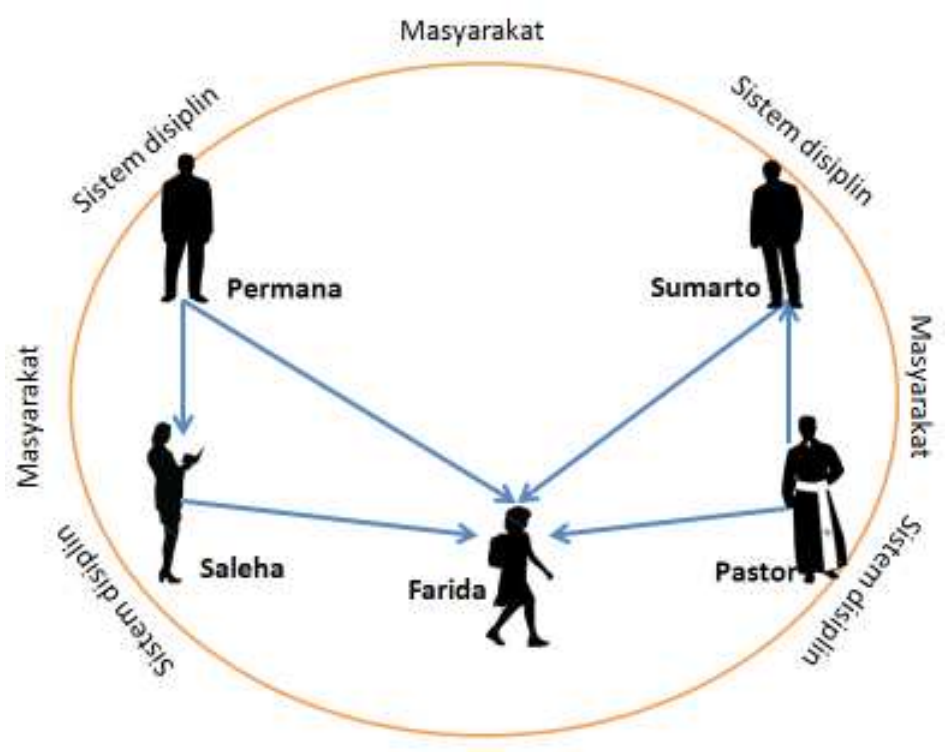

Bagan 2.1 Relasi antar tokoh dalam Novel Keluarga Permana 
menentukan apa yang tokoh lakukan. Tokoh-tokoh dalam novel ini, menjadi objek kuasa, namun di saat yang bersamaan pula ia menjadi pengawas atau penjamin sistem disiplin, agar sistem tersebut tetap ada. Bagan di bawah ini menerangkan bagaimana relasi antar tokoh dalam novel ini.

Bagan 2.1 menjelaskan bagaimana relasi antar tokoh (utama) dalam novel ini. Relasi itu dimulai dari sistem disiplin yang bekerja dalam benak tiap tokoh yang kemudian menjadi motivasi tindak-tanduk tokoh pada tokoh lain, misalnya sistem disiplin dalam benak tokoh Permana yang kemudian menjadi motivasi perilakunya terhadap tokoh Saleha dan Farida. Pada bagan tersebut terlihat bagaimana Farida benar-benar menjadi objek kekuasaan. Hal tersebut terlihat bagaimana semua tokoh mencoba mendisiplinkan Farida. Hal itu ditunjukan dengan anak panah yang mengarah kepadanya. Sementara itu, Masyarakat menjadi pengawas sistem disiplin, begitu juga setiap tokohnya. Jadi, ada sebuah kondisi di mana tokoh menjadi objek kekuasaan, namun pada momen yang sama ia juga menjadi penjamin sistem disiplin, menjadi kepanjangan tangan dari kekuasaan. Untuk lebih jelasnya, uraian pada bagian selanjutnya menerangkan lebih seksama mengenai relasi antar tokoh dan apa dan bagaimana sistem disiplin itu bekerja.

Plang! Tangan Permana Melayang menempeleng muka istrinya yang seketika itu juga mendesah lalu merunduk. Tetapi Saleha menahan diri untuk tidak melepaskan tangisnya. Ia menggigil. (Ramadhan KH., 1986: 34)

Kutipan di atas menggambarkan relasi kuasa antara tokoh Permana dan Saleha. Gambaran mengenai keluarga ideal dalam benak Permana telah menjadi sistem disiplin bagi dirinya, bahwa ia harus tunduk pada sistem disiplin itu. Apabila tidak memenuhi gambaran tersebut, perasaan bersalah akan menghukumnya, masyarakat akan pula menghukumnya; tentu saja dengan perasaan bersalah itu.

Sistem disiplin, yakni gambaran keluarga ideal yang dimaksud ialah gambaran mengenai fungsi-fungsi anggota dalam keluarga, misalnya fungsi ayah dalam keluarga ialah mencari nafkah; ibu mengurus rumah; dan anak belajar. Apabila seseorang melanggar dalam arti tidak memenuhi fungsinya dalam gambaran keluarga ideal, ia akan mendapat hukuman itu. Namun, seseorang atau objek kuasa itu senantiasa berusaha untuk tidak menjadi pelanggar. Di sinilah hal yang menarik, bagaimana usaha seseorang itu agar ia tidak jadi pelanggar?

Dalam novel ini, diceritakan bahwa Permana dipecat dari pekerjaannya. Hal tersebut menyebabkan ia menjadi pengangguran, sementara Saleha, 
istirnya, malahan bekerja mencari nafkah bagi keluarga. Dalam gambaran keluarga ideal, Permana tentu saja tidak masuk dalam fungsinya. Ia malahan menjadi pengangguran dan beban keluarganya. Pengangguran bagi seorang laki-laki adalah kekurangan bahkan mungkin menjadi aib. Ketika seorang lakilaki tidak bekerja, ia diasumsikan sebagai seseorang yang malas dan tidak berguna.

Foucault juga melihat kegilaan (pengangguran dan kemiskinan) sebagai suatu penyakit dalam masyarakat pada abad ke-17. Pada abad ke-17 kepekaan sosial mulai terbentuk. Harus ada tindakan untuk mengatasi persoalan sosial, seperti kemiskinan, pengangguran, dan kegilaan. Untuk mengatasi hal itu, dibangunlah "rumah koreksi" yang berisi pengangguran, orang malas, orang sakit, geladangan, orang gila, dll. Pada tahap ini, masalah sarana menjadi berubah; kapal ialah tempat pemberangkatan, sementara rumah koreksi menjadi tempat pengurungan (1967: 46-48).

Latar waktu pada novel ini sekitar tahun 1970-an — sebagaimana novel ini diterbitkan. Masyarakat menganggap dan menanggapi kegilaan (dalam hal ini pengangguran) tentu saja melalui cara yang berbeda dengan masyarakat pada abad ke-17. Dalam novel ini, orang yang menganggur tidak direhabilitasi, tetapi ditekan, diancam, dan dihukum secara sosial. Hukumannya yakni dengan rasa bersalah, mungkin cibiran, dan umpatan.

Tentu saja Permana merasakan bagaimana lingkungan sosial menekannya, atau bahkan dirinya sendiri yang menghukumnya. Sebagai penganggur, ia tidak memiliki kekuatan dan kekuasaan dalam hal ekonomi. Oleh sebab itu, ia mencari kekuasaan lain yang dapat mempertahankan eksistensinya sebagai suami dan laki-laki. Akhirnya ia menggunakan kekuasaan laki-lakinya itu, yakni superioritas laki-laki yang diwariskan dari budaya patriarkat. Ia pun kemudian merepresi istrinya, Saleha, dengan tindakan-tindakan kasar.

Namun, superioritas itu tidaklah cukup. Ia sangat membutuhkan kekuatan dan kekuasaan dalam hal ekonomi. Oleh sebab itu, untuk mempertahankan fungsinya sebagai "si pencari nafkah", ia berinisiatif menyewakan sebuah kamar di rumahnya. Itulah cara bagaimana Permana melepaskan dirinya dari hukuman.

Selain kepada istrinya, Permana juga melakukan tindakan kekerasan kepada anaknya, Farida. Hal tersebut memiliki beberapa sebab, yaitu hal tersebut adalah wujud frustrasinya karena fungsinya sebagai kepala keluarga tidak berjalan dan itu merupakan wujud untuk mempertahankan kewibawaan 
dan superioritasnya sebagai kepala keluarga dan laki-laki yang tengah "goyah". Kutipan di bawah ini menunjukan hal tersebut.

Dengan terpatah-patah Ida menceritakan pengalamannya yang baru saja terjadi. Dia dipukuli ayahnya, dicambuk dengan rotan panjang yang sudah biasa tersedia di atas lemari pakaian. Sebelum itu ayahnya telah memukuli dan menendang ibu Ida yang kemudian lari entah ke mana. (Ramadhan KH., 1986: 23)

Relasi kuasa antara tokoh Permana dan Saleha terhadap tokoh Farida terlihat jelas saat Farida hamil. Saat itu, Permana dan Saleha berusaha menggugurkan kandungan Farida dengan meminumkan obat kepadanya. Mengapa hal tersebut dilakukan? Tak lain karena Permana dan Saleha merasa jika Farida ketahuan hamil di luar nikah, nama keluarga mereka akan tercoreng. Keluarga mereka tidak lagi dianggap sebagai keluarga yang ideal dan mematuhi norma kesusilaan, di mana kehamilan terjadi setelah terjadinya pernikahan.

Demikian, masyarakat akan menilai keluarga Permana. Sementara, penilaian Permana dan Saleha terhadap Farida ialah bahwa Farida adalah immoral atau telah melanggar norma agama Islam dan kesusilaan dalam konteks budaya Sunda. Permana dan Saleha yang juga merupakan anggota masyarakat memiliki hak untuk melakukan tindakan atas Farida agar ia "normal" kembali. Caranya tak lain seperti yang telah disebutkan di atas, yaitu meminumkan obat penggugur kandungan kepada Farida. Kutipan di bawah ini memperlihatkan bagaimana rasa malu apabila kehamilan itu diketahui oleh orang lain (masyarakat) menjadi motivasi utama mengapa Saleha meminumkan obat kepada Farida.

Sudah beberapa hari Ida memaksakan diri minum obat dari duku itu. Ia menguatkan diri menghabiskannya. Sebab sebenarnya sejak tegukan pertama ia sudah mau memuntahkannya. . . Tapi Saleha memaksanya. Dan yang paling mendorongnya hingga mampu minum obat itu sampai tak tersisa, adalah gambaran yang diberikan oleh ibunya, bahwa Saleha akan sangat malu kalau sampai Ida tidak tertolong, kalau perutnya jadi besar (Ramadhan KH., 1986: 92).

Apa yang telah dipaparkan di atas terlihat bagaimana masyarakat menjadi tokoh yang penting dalam novel ini, padahal masyarakat nyaris tidak tampak secara fisikal sebagai tokoh. Kendatipun begitu, masyarakat sebagai penjamin sistem disiplin memiliki pengaruh yang besar dalam tindak-tanduk tokoh. Dalam beberapa adegan, tindakan tokoh dipicu oleh keinginan masyarakat. 
Masyarakat sebagai tokoh dalam novel ini pun posisinya cukup fleksibel. Maksudnya, ia bisa merujuk pada populasi yang besar, namun ia juga dapat merujuk pada individu sebagai representasi (wakil) dari masyarakat. Misalnya, pada tahap tertentu Permana dan Saleha bisa bertindak sebagai wakil atau representasi dari masyarakat; pada tahap lainnya tokoh Mang Ibrahim dan Nenek Lengkong juga bisa bertindak sebagai wakil dari masyarakat; pada tahap lainnya Sumarto dan Pastor pun demikian.

Mengenai relasi antara tokoh Farida dan Sumarto sangat menarik untuk dijelaskan. Apa yang menyebabkan tokoh Farida hamil tak lain ialah paksaan tokoh Sumarto untuk melakukan hubungan seksual pranikah. Sistem kekuasaan pun bekerja pada tahap ini. Gambaran mengenai dominasi dan superioritas lakilaki terhadap perempuan menjadi motivasi Sumarto untuk menaklukan Farida. Superioritas itu tentu saja lahir dari kebudayaan yang ada dalam masyarakat patriarkat, dan kemudian itu merasuk dalam alam bawah sadar Sumarto. Superioritas Sumarto terlihat pada kutipan di bawah ini

Mengapa pula aku jamah dia? Mengapa aku rayu dia waktu itu? Mengapa aku dekap dia?. . Mengapa pula aku khilaf melakukannya dengan cara yang bodoh sekali, cuma karena karena dorongan nafsu, cuma karena menganggap enteng. Bukankah Ida pernah membisikkan, bahwa sepantasnya hal itu dilakukan nanti saja, nanti saja setelah kawin, tapi aku merayunya juga sampai ia menyerah? (Ramadhan KH., 1986: 103).

Kutipan tersebut berisi penyesalan tokoh Sumarto tapi sekaligus menggambarkan superioritasnya. Ia merayu atau cenderung memaksa Farida untuk melakukan tindakan immoral. Dalam hal ini Farida sangat rasional. Ia memahami etika yang berlaku dalam masyarakat bahwa hubungan seks pranikah adalah terlarang. Namun, superioritas itu telanjur kuat bekerja dalam benak Sumarto. Akhirnya, Farida hamil karena hubungan seks itu.

Pada tahap-tahap berikutnya, Sumarto merasa menyesal atas tindakannya itu. Ia merasa bahwa ia telah berdosa. Perasaan bersalah itu tak lain merupakan bukti bahwa sistem disiplin (yang lain, selain "superioritas laki-laki”) telah bekerja pula dalam alam bawah sadar Sumarto. Sistem disiplin tersebut berupa etika dan norma kesusilaan masyarakat dan etika Kristen. Dalam wilayah etika dan norma kesusilaan masyarakat, Sumarto merupakan seseorang yang immoral. Sementara dalam wilayah etika Kristen, Sumarto merupakan

\footnotetext{
${ }^{1}$ Sepuluh perintah Allah terdapat pada Keluaran 20:2-17 dan Ulangan 5:6-21; di antara sepuluh perintah tersebut salah satunya terdapat perintah Jangan berzinah (Keluaran 20:14).
} 
seseorang yang berdosa. Ia telah melanggar sepuluh perintah Allah. ${ }^{1}$ Dengan begitu, rasa bersalah dan dosa menjadi hukumannya.

Oleh sebab Sumarto merasa bahwa dirinya bersalah dan berdosa, ia pun pergi ke tokoh Pastor untuk "menormalkan" dirinya dengan menjalani pengakuan dosa. Di sinilah terjadi relasi kuasa antara tokoh Pastor dan Sumarto. Hal ini seperti hubungan pasien dan dokter yang dikonsepkan oleh Foucault, di mana melalui ilmu kedokterannya sang dokter memiliki kuasa atas pasiennya dalam menentukan suatu penyakit. Lebih jauh ia menerangkan (2002: 218-219) bahwa kedokteran tidak hanya diperankan sebagai sebuah ilmu untuk menyembuhkan orang sakit. Kedokteran bisa dipandang sebagai mesin kekuasaan. Peran itu berkembang pada abad ke-18, di mana dokter ikut berpartisipasi dalam perebutan kekuasaan sosial.

Dokter menjadi pengawas terhadap kesehatan masyarakat dan menjaga populasi. Atas dasar itu, secara otomatis ia memegang kekuasaan atas manusia. Ia dapat memberi definisi tentang seseorang secara medis, melakukan tindakan atasnya, dan menyembuhkannya. Bahkan kekuasaan dokter tidak hanya berada dalam ruang praktik atau rumah sakit, ia memiliki kekuat an untuk mengatur tingkah laku manusia dari makanan, seksualitas dan kesuburan, pakaian, dan penetapan ruang kehidupan.

Seperti yang telah disebutkan sebelumnya bahwa dalam hal ini dokter memiliki posisi yang sama dengan pastor. Melalui ilmu agama, ia berhak menentukan seseorang berdosa atau tidak, seseorang kafir atau tidak. Lebih dari itu, ia memiliki pengaruh terhadap suatu zaman. Pastor memiliki kekuatan mengat ur tingkah laku manusia. Dalam hal novel ini, tokoh Pastor berhak melakukan sesuatu terhadap Sumarto, yakni mengatasi dosa dan rasa bersalah. Sebagaimana konsultasi dokter dengan pasien, pengakuan dosa menjadi medan di mana relasi kuasa bisa begitu nyata antara pastor dan jemaatnya. Dalam pengakuan dosa tersebut, Pastor tersebut memiliki hak untuk membuat Sumarto menjadi orang yang taubat, menjadi Kristen yang taat menurut ilmu agama.

Di sisi lain, jika ditinjau dari perspektif Kristen, pengakuan dosa menjadi sangat penting bagi umat Kristen. Ketika seseorang melakukan dosa, wajib baginya untuk mengakui dosa tersebut dan meminta maaf kepada Allah, kemudian dosa itu pun diampuni. Hal tersebut termaktub pula dalam Yohanes 1:8.

Relasi kuasa antara Sumarto, Pastor, dan Farida juga menarik unt uk dilihat. Hal ini dikarenakan relasi pada bagian inilah yang menentukan keimanan tokoh 
Farida. Seperti yang telah diceritakan pada bagian sebelumnya bahwa tokoh Farida akhirnya pindah agama. Hal tersebut tentu saja dipengaruhi oleh relasi kuasa Sumarto dan Pastor.

Kondisi Farida sudah demikian mengkhawatirkan karena kandungannya telah gugur. Farida takut tidak ada laki-laki lain yang akan menerimanya kelak, dengan kondisi yang tidak perawan itu. Ia hanya berpikir hanya Sumarto-lah yang dapat ia jadikan pegangan hidup, hanya Sumarto-lah yang dapat menerimanya. Dari sini saja telah terlihat bagaimana inferioritas Farida. Peran budaya Timur pun berlaku pada tahap ini, di mana keperawanan menjadi hal yang sangat penting, dan itu pula-lah yang menjadi ganjalan di hati Farida. Dalam tahap ini dapat dilihat pula bagaimana superioritas laki-laki berdampak besar dalam kehidupan dan pola pikir tokoh Farida.

Dalam kondisi yang demikian, Farida dan Suamrto berniat untuk menikah, namun dengan catatan bahwa Sumarto tetap berpegang pada keimanannya sebagai Kristen. Artinya, Farida-lah yang harus merubah keimanannya dari seorang muslimah ke kristian. Pertanyaannya, mengapa Sumarto tidak ingin mengubah keimanannya. Ada beberapa alasan: (1) superioritas Sumarto sebagai laki-laki atau budaya patriarkat yang mengakar dalam diri Sumarto; (2) gambaran manusia yang memiliki keimanan yang benar; dan (3) perkembangan keimanan Sumarto. Kutipan di bawah ini menunjukan superioritas Sumarto sebagai laki-laki dan budaya patriarkat yang telah mengakar dalam diri Sumarto.

"Bagaimana soal agama kita?"

Sumarto diam sejenak. Tapi kemudian ia nyatakan perasaannya yang sudah lama dikandungnya. Ia tetap merasa, ia mesti menjadi kepala keluarga, ia tetap merasa mesti menjadi nahkoda di kapal rumah tangganya. Ia mau supaya calon istrinya mengikutinya, tunduk padanya, agar tidak ada nahkoda lain di atas kapal itu, selain dirinya. Itulah ajaran yang ia dapatkan dar orang tuanya, yang ia resapkan dan ia yakini kebaikannya (Ramadhan KH., 1986: 126).

Ida ingat. Memang benar Sumarto sudah cerita tentang hal itu. Ia takkan bisa pindah agama. Ia masih ingat akan ketegasannya, bahwa ia tetap terikat oleh agamanya untuk seumur hidup. Dan sekarang, dalam keadaan seperti sekarang, dirasakannya tidak ada jalan lain yang lebih baik untuk menolong

\footnotetext{
${ }^{2}$ Pasal Galatia 3:27-29 berbunyi, "Kamu semua, yang telah dibaptis dalam Krist us, telah mengenakan Kristus. Dalam hal ini tidak ada orang Yahudi atau Yunani, tidak ada hamba at au orang merdeka, tidak ada laki-laki atau perempuan, kerena kamu semua adalah satu di dalam Kristus. Dan jikalau kamu adalah milik Kristus, maka kamu juga adalah keturunan Abraham (dan tent unya juga Sarah) dan berhak menerima janji”.
} 
dirinya, selain ia mengikuti keinginan kekasihnya, tunduk pada kekasihnya. Ia merasa takut kalau-kalau Sumarto akan mundur lagi dari niatnya kalau hal itu dikutik-kutik. Ia mendambakan ketenangan, menghasratkan perasaan damai (Ramadhan KH., 1986: 127).

Selain mengenai itu, hal yang penting pada tahap ini ialah gambaran mengenai manusia yang memiliki keimanan yang benar-dan ini berlaku pula untuk tokoh Pastor. Maksudnya, Sumarto dan Pastor tent u saja memiliki gambaran mengenai seseorang yang berada dalam keimanan yang benar. Bagi Sumarto dan Pastor, seluruh manusia berada pada keimanan yang salah, kecuali umat Kristen. Dalam hal ini, Sumarto dan Pastor melihat bahwa Farida (yang Islam) berada pada jalan keimanan yang salah atau sesat. Oleh sebab itu, Sumarto dan Pastor ingin menguasai Farida dengan cara mengubah keimanan Farida dari Islam ke Kristen. Mereka berusaha "menyembuhkan" Farida, menunjukan jalan yang benar dari kesesatan. Akhirnya, Farida pun dibaptis.

\section{Sistem Disiplin dan Perkembangan Keimanan Tokoh Farida}

Tentu saja seseorang menjadi Kristen setelah ia dibaptis, seperti yang termaktub dalam Galatia 3:27-29. ${ }^{2}$ Namun, dalam novel ini, apakah demikian adanya? Justru inilah yang menjadi persoalan. Pada bagian ini akan diuraikan mengenai keimanan tokoh Farida. Hal ini menjadi menarik karena tokoh Farida yang telah dibaptis ternyata masih memegang teguh keimanannya yang dahulu, yakni Islam. Hal ini tentu saja dipengaruhi oleh perkembangan keimanan Farida dari tahap pertama hingga ketiga.

Dalam konsep James Fowler, perkembangan keimanan tokoh Farida-jika ditinjau dari segi usia—berada pada tahap ketiga, yakni "Synthetic Conventional Faith". Pada tahap ini, seseorang masih berpikir secara abstrak. Ia baru membentuk sistem kepercayaannya. Pada tahap ini identitas dirinya belum matang atau masih dalam proses mencari. Hal tersebut menyebabkan seseorang yang berada pada tahap ini cenderung menyesuaikan diri dengan keimanan orang lain sebagai panduan moral. ${ }^{3}$

\footnotetext{
${ }^{3}$ Lihat artikel Fred Hughes yang berjudul "Concept of Faith Development-An Evangelical Perspective" yang diterbitkan Jurnal Whiteflield Briefing edisi November 1997 (Vol. 2 No. 5). Dalam artikel tersebut diterangkan mengenai tahapan perkembangan keimanan menurut James Fowler. Tahapan-tahapan tersebut antara lain: (1) Int uitive-projective faith (usia 0 sampai 7 atau 8 tahun), (2) Mythic-literal faith (usia 7 sampai 11 atau 12 tahun), (3) Synthetic-Conventional Faith (usia 12 sampai 17 atau 18 tahun), (4) IndividuativeReflactive Faith (usia 17 atau 18 sampai 20 tahun), (5) Balanced Faith (sampai usia 50-an tahun), dan (5) Universalizing Faith.
} 
Hal tersebut berarti tokoh Farida belum memiliki keimanan yang matang. Ia masih melihat orang lain, terutama ibu dan ayahnya. Namun, keluarga Permana bukanlah keluarga yang agamis. Pendidikan agama tokoh Farida didapatkan dari Nenek Lengkong dan Mang Ibrahim. Farida pun tidak rajin sembahyang. Oleh sebab itu, rasanya sangat mungkin bilamana Farida berpindah agama.

Selain faktor pendidikan agama, hal yang paling kuat mendorong Farida berpindah agama ialah ketergant ungannya pada sosok Sumarto. Pertama, superioritas Sumarto menjadi penyebab ketergantungan Farida, selain itu, nampaknya Sumarto telah menjadi kedamaian bagi Farida di tengah konflik dalam keluarganya. Itulah sebabnya, mengapa Farida mau mengikuti kehendak Sumarto untuk masuk agama Kristen.

Sementara itu, pada kutipan sebelumnya telah dijelaskan bahwa Sumarto tidak bisa berpindah keyakinan. Merujuk pada konsep James Fowler, jika dilihat dari usianya, Sumarto telah masuk pada tahap keimanan yang telah matang, yakni tahap "Balance Faith". Keimanan Sumarto pun telah diperkuat oleh tokoh Pastor.

Pada bagian sebelumnya dijelaskan bahwa Sumarto melakukan pengakuan dosa. Hal tersebut menunjukkan ketaatan dan kemengertian Sumarto atas agamanya. Ia mengetahui cara bertaubat dan menjadi manusia baru kembali. Sementara di sisi lain, Farida nampak sibuk dengan penyesalannya. Dalam teks novel, nampaknya tidak ada upaya Farida untuk mendekatkan diri kepada Tuhannya. Begitu pun dengan Permana dan Salehah, mereka malah menyelamatkan wajah mereka dari rasa malu akibat kehamilan Farida. Hal ini nampaknya wajar karena keluarga Permana sendiri bukanlah keluarga yang taat.

Kendati belum memiliki keimanan dan ketakwaan yang matang, Farida ternyata tidak sungguh-sungguh memeluk keimanan yang barunya, yakni Kristen. Hal tersebut terlihat ketika Farida dibaptis. Pada saat itu ia menangis dan merasa tak yakin dengan apa yang dilakukannya. Selain itu, Farida juga sempat bercerita kepada ibunya bahwa ia hanya terpaksa masuk agama Kristen. kemudian, saat ia meninggal Farida mengucapkan kalimat tauhid. Berikut kutipannya:

... Sementara hatinya (Farida) masih memihak kepada keyakinannya yang lama, kepada ajaran yang pernah diberikan oleh Nenek Lengkong sewaktu ia masih kecil sekalipun jauh dari mendalam (Ramadhan KH., 1986: 139). 


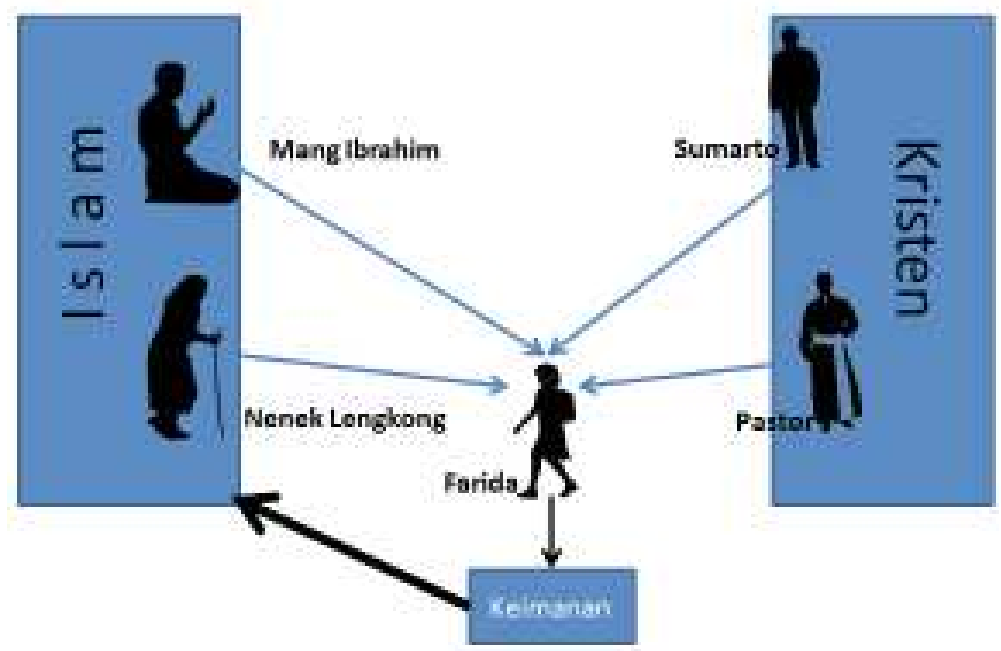

Bagan 2.2 Kecenderungan Keimanan Farida

"Saya terpaksa, terpaksa, Mamah. Tidak ada pilihan lain. Cuma dia yang bisa menolong saya. Tak ada yang lain. Tidak ada laki-laki yang lain. Ampunilah saya, Mamah, ampunilah saya. ...” (Ramadhan KH., 1986: 18).

Perawat yang lainnya memegang pergelangan tangan wanita yang celaka itu. Ia cemas. Ia punya firasat. Hatinya bergetar. Ia berbisik pada telinga Ida:

"Allahu Akbar, Allahu Akbar, Allahu Akbar. La illaha illa'llah. La illaha illa'llah. La illaha illa'llah."

Pengantin baru itu kelihatan mengikutinya, ia mengucapkan kalimat suci itu dengan halus sekali, dengan perlahan-lahan sekali. Sesudah itu hilanglah dia. Firasat perawat itu benar (Ramadhan KH., 1986: 10).

Meskipun dalam konsep James Fowler tokoh Farida masuk pada tahap "Synthetic Conventional Faith", yakni tahap di mana keimanan belum sempurna, masa lalu Farida sebagai anak kecil yang mendapat pelajaran agama dari Mang Ibrahim dan Nenek Lengkon tidak serta-merta hilang. Ajaran itu masih melekat kuat dalam diri Farida mengalahkan keyakinan yang diberikan Pastor dan Sumarto.

Bagan 2.2 memperlihatkan kecenderungan keimanan tokoh Farida. Meskipun ia telah dibaptis, tokoh ini pada akhirnya masih berpegang teguh pada keyakinannya yang dahulu, Islam. Sistem disiplin mengenai gambaran manusia yang berimana dalam pandangan Kristen tidak berlaku terhadap Farida. Farida tetap pada keyakinannya sebagai Islam. Hal tersebut karena dalam diri Farida tertanam pula sistem disiplin mengenai gambaran muslimah 
yang taat. Farida melihat bahwa ketika ia menjadi Kristen secara utuh, ia telah melanggar sistem disiplin itu. Di samping itu, Nenek Lengkong dan Mang Ibrahim berperan besar dalam perkembangan keimanan tokoh Farida.

Hal ini memperlihatkan bahwa relasi kuasa antara tokoh Farida, Sumarto, dan Pastor dalam hal agama tidak-lah kuat mengubah Farida. Motivasi Farida untuk masuk Kristen tak lain karena inferioritas Farida sebagai perempuan, atau ketergantungan Farida terhadap Sumarto, dan superioritas Sumarto terhadap Farida. Hal ini menunjukan bahwa dalam novel ini, keimanan Farida tidak dapat dikuasai secara utuh oleh Sumarto dan Pastor.

\section{Simpulan}

1. Melalui pendekatan kekuasaan Foucault didapat bahwa sistem disiplin bekerja dalam alam bawah sadar setiap tokohnya. Pertama, masayarakat muncul sebagai tokoh yang penting. Ia berfungsi sebagai pengawas sistem disiplin itu. Dalam novel ini, seperti apa yang dikatakan Foucault, kekuasaan saling bertumpang-tindih dan kompleks. Kedua, masing-masing tokoh mencoba untuk bertahan dari pengaruh kekuasaan itu, sekaligus menjadi pengawas sistem disiplin atau kekuasaan (menguasai). Sistem disiplin ini bekerja pula pada keimanan tokoh Farida.

2. Sementara itu, jika dilihat dari konsep perkembangan keimanan James Fowler, tokoh Farida berada pada tahap ketiga at au tahap "Synthetic Conventional Faith". Dengan begitu, keimanan Farida masih mungkin goyah. Itulah sebabnya ia menyetujui untuk masuk agama Kristen sesuai saran dan paksaan Sumarto. Namun, pada akhirnya ia tetap pada keislamannya. Hal tersebut karena nilai-nilai keislaman telah ditanamkan sejak kecil, meskipun tidak terlalu kuat, itulah yang menjadi bekal pertahanan keimanan Farida. Pendisiplinan yang dilakukan Sumarto dan Pastor dengan cara membaptis Farida pada akhirnya tidak mengubah keimanan Farida.

\section{Daftar Pustaka}

Bertens, K. 2001. Etika. Jakarta: Gramedia Pustaka Utama.

Bartky, Sandra Lee. 1990. Feminity and Domination; Studies in the Phenomenology of Oppression. New York dan London: Routledge.

Foucault, Michel. 2008. La Volonte de Savior: Histoire de la Sexualité. Jakarta: YOI. . 1961. Madness and Civilization. London: Tavistock. 
. 2002. Power/Knowledge. Yogyakarta: Bentang Budaya.

Hughes, Fred. 1997. "Concept of Faith Development-An Evangelical Perspective”. Journal Whiteflield Briefing edisi November 1997 (Vol. 2 No. 5).

Haryatmoko. 2013. "Kekuasaan Melahirkan Anti-Kekuasaan" disampaikan dalam kuliah Filsafat Ilmu Pengetahuan FIB UI pada tanggal 24 Oktober 2013: tidak diterbitkan.

Lembaga Alkitab Indonesia. 1977. Alkitab. Jakarta: LAI.

Ramadhan K.H. 1986. Keluarga Permana. Jakarta: Pustaka Jaya

Rosidi, Ajip. 1977. Ikhtisar Sejarah Sastra Indonesia. Bandung: Putra A. Bardin.

Saridjo, Marwan. 2006. Sastra dan Agama: Tinjauan Kesusastraan Indonesia Modern Bercorak Islam. Jakarta: Yayasan Ngali Aksara. 